\title{
Guru dan Kualitas Pendidikan: Sebuah Tinjauan
}

\section{Bambang Widiatmoko}

Pengajar Ilmu Humaniora di Universitas Islam 45 Bekasi, Alumnus Fakultas Ilmu Budaya - Universitas Padjadjaran dan Pasca Sarjana Unisma Bekasi.

\section{Abstract}

This research aims to analyze the relationship of teacher perception about school master supervision and teacher job motivation with teacher competence of pedagogy. The unit analysis of this research is Senior Islamic High School (Madrasah Aliyah Negeri - MAN) in Bekasi City, Jawa Barat. Hypothesis testing used is regression analysis. Regression analysis method's result show that, first: teacher perception about school master supervision and teacher competence of pedagogy has positive relationship. Second: there is positive relationship between teacher job motivation and teacher competence of pedagogy, and third: there is positive relationship between teacher perception about school master supervision and teacher job motivation with teacher competence of pedagogy in Madrasah Aliyah Negeri Bekasi.

\author{
Keywords \\ teacher perception; supervision; \\ competence of pedaqogr
}

\section{Pendahuluan}

Guru sebagai unsur manusia memiliki peran strategis dalam menggerakkan aktivitas pendidikan. Guru merupakan ujung tombak dalam upaya peningkatan kualitas layanan, proses, dan hasil pendidikan.

Kualitas pendidikan secara keseluruhan tidak dapat dipisahkan dari kualitas guru. Guru merupakan kunci utama yang memiliki peran besar dalam peningkatan mutu pendidikan. Guru berada pada titik sentral setiap usaha perbaikan pendidikan yang diarahkan pada perubahan seluruh aspek, seperti kurikulum, metode, dan pengembangan sarana dan prasarana. Perubahan dan perbaikan aspek-aspek tersebut tidak akan bermakna apabila tidak melibatkan guru sebagai pelaku pendidikan.

Sebagai pelaksana langsung pendidikan yang memiliki tugas pokok memfasilitasi kegiatan belajar siswa, guru dituntut melaksanakan tugas secara profesional, kreatif dan dinamis sehingga siswa dapat memposisikan dirinya sebagai subjek belajar.

Guru merupakan komponen paling menentukan dalam sistem pendidikan secara keseluruhan, yang harus mendapatkan perhatian sentral, pertama dan utama. Guru memegang peranan utama dalam pembangunan pendidikan, khususnya yang diselenggarakan secara formal di sekolah. Guru juga sangat menentukan keberhasilan peserta didik, terutama dalam kaitannya dengan proses belajar-mengajar. Guru merupakan komponen yang paling berpengaruh terhadap terciptanya proses dan hasil pendidikan yang berkualitas. Oleh karena itu, upaya perbaikan apa pun yang dilakukan untuk meningkatkan kualitas pendidikan tidak akan memberikan sumbangan yang signifikan jika tidak didukung oleh guru yang profesional dan berkualitas. 
Pembinaan profesi guru, termasuk pembinaan kompetensi pedagogik, merupakan hal mutlak yang tidak dapat ditawar-tawar. Hal ini berlaku bagi semua jenis pendidikan dan institusi pendidikan, baik yang berada di bawah naungan KementerianPendidikan dan Kebudayaan maupun yang berada di bawah naungan Kementerian Agama Republik Indonesia. Dalam konteks lembaga pendidikan madrasah, aktivitas pengembangan dan pembinaan kompetensi pedagogik guru merupakan wewenang dan tanggung jawab Direktorat Pendidikan Madrasah, Direktorat Jenderal Pendidikan Islam, Kementerian Agama RI.

Madrasah Aliyah adalah sekolah menengah umum yang berciri khas agama Islam yang diselenggarakan oleh pemerintah maupunoleh pihak swasta. MA merupakan faktor pelengkap dalam sistem pendidikan nasional Indonesia yang berdasarkan Pancasila. Dengan demikian, kedudukan madrasah aliyah sebagai pusat pembinaan sumber daya manusia bangsa Indonesia sangat strategis.

Dalam Keputusan Menteri Agama Republik Indonesia Nomor 370 tahun 1993tentang Madrasah Aliyah, Pasal 2, dinyatakan bahwa tujuan pendidikan di madrasah aliyah adalah: (1) Meningkatkan pengetahuan siswa untuk melanjutkan pendidikan pada jenjang yang lebih tinggi; (2) Meningkatkan pengetahuan siswa untuk mengembangkan diri sejalan dengan perkembangan ilmu pengetahuan, teknologi dan kesenian yang dijiwai ajaran agama Islam; (3)Meningkatkan kemampuan siswa sebagai anggota masyarakat dalam mengadakan hubungan timbal balikdengan lingkungan sosial, budaya dan alam sekitarnya yang dijiwai ajaran agama Islam.

Untuk dapat mencapat tujuan tersebut, lembaga MA perlu dikelola secara profesonal. Sehubungan dengan itu, Keputusan Menteri Agama Republik Indonesia Nomor 370 tahun 1993, Bab V,Pasal 5 ayat (2) menyatakan bahwa pengelolaan madrasah aliyah meliputi:

a. Peserta didik

b. Guru dan tenaga kependidikan lainnya;

c. Kurikulum;

d. Kegiatan belajar mengajar;

e. Sarana;

f. Prasarana;

g. Administrasi madrasah;

h. Ketertiban dan keamanan

Fakta menunjukkan bahwa pengelolaan lembaga madrasah aliyah di berbagai daerah di Indonesia, baik madrasah aliyah negeri maupun yang dikelola oleh swasta masih menghadapi banyak kendala.Salah satu di antara permasalahan tersebut adalah masalah guru.

Guru sebagai subsistem pada lembaga pendidikan tidak terlepas dari subsistem lain yang memiliki garis instruksional, yaitu kepala sekolah sebagai manajer yang berwewenang mengelola dan mengendalikan sistem sekolah secara keseluruhan, termasuk dengan mengadakan supervisi. Kegiatan supervisi kepala sekolah terkait dengan proses kerja, upaya penyelesaian masalah kerja sehingga terjadi perbaikan dan peningkatan kualitas proses kerja.

Dalam Peraturan Menteri Pendidikan Nasional No. 13 tahun 2007 tentang Standar Kepala Sekolah/Madrasah, bagian lampiran,dijelaskan bahwa kepala sekolah/madrasah dipersyaratkan memiliki sejumlah kompetensi, salah satu di anataranya adalah kompetensi supervisi. Kompetensi bidang supervisi meliputi tiga aspek, yaitu:

1. Merencanakan program supervisi akademik dalam rangka peningkat- an profesionalisme guru;

2. Melaksanakan supervisi akademik terhadap guru dengan mengguna- kan pendekatan dan teknik supervise yang tepat; 
3. Menindaklanjuti hasil supervisi akademik terhadap guru dalam rangka peningkatan profesionalisme dengan menggunakan pendekatan dan teknik supervisi yang tepat.

Pada sisi lain, terdapat sejumlah aspek internal sebagai atribut individu yang berpengaruh terhadap kinerja, di antaranya adalah faktor motivasi guru dalam menjalankan tugas dan tanggung jawabnya.

Motivasi kerja guru merupakan totalitas yang dimiliki oleh seorang guru untuk melaksanakan pekerjaan dalam upaya mencapai kesuksesan. Seorang guru yang memiliki motivasi tinggi dapat berperan dalam situasi apa pun dan mampu merefleksikan seluruh kapasitas yang dimilikinya dalam menghadapi berbagai tantangan dan situasi kerja. Motivasi kerja tinggi yang dimiliki oleh seorang guru melahirkan cara berpikir positif dan perilaku kerja yang sehat untuk mencapai tujuan organisasi sekolah.

Di wilayah administratif Kota Bekasi terdapat dua madrasah aliyah berstatus negeri yaitu Madrasah Aliyah Negeri I dan Madrasah Aliyah Negeri 2 Bekasi.Kedua lembaga ini menghadapi sejumlah masalah, baik dalam hal pengelolaan lembaga maupun dalam hal kinerja mengajar guru.

Asro'i (2013) melakukan studi tentang kinerja mengajar guru madrasah aliyah se-kota Bekasi. Peneliti menyimpulkan bahwa dalam hal kepe- mimpinan kepala madrasah, budaya madrasah, motivasi kerja, komitmen kerja, dan kinerja mengajar guru madrasah aliyah sekota Bekasi terdapat beberapa aspek yang masih lemah.Hasil penelitian juga menyatakan bahwakepemimpinan kepala madrasah, budaya madrasah, motivasi kerja, dan komitmen kerja guru madrasah aliyah di Bekasi harus lebih ditingkatkan karena berdampaksignifikan terhadap kinerja mengajar guru di madrasah aliyah.

Penelitian lain yang relevan adalah studi tentang problem dan solusi pengelolaan madrasah aliyah di Indonesia. Salah satu temuan dalam penelitian ini adalah: tidak seluruh guru madrasah aliyah di Indonesia memiliki kompetensi profesional, pedagogik, etik, dan sosial; demikian pula dalam memahami dan mengembangkan kurikulum yang digunakan.

Pelaksanaan supervisi kepala sekolah pada satu sisi dan kondisi objektif motivasi kerja guru pada sisi lain merupakan suatu kondisi yang kondusif bagi terselenggaranya kegiatan belajar mengajar yang baik, termasuk di madrasah aliyah. Dengan demikian, perlu dilakukan penelitian mengenai pelaksanaan supervisi kepala sekolah dan hubungannya dengan motivasi kerja guru dan kompetensi pedagogik guru madrasah aliyah negeri di Kota Bekasi.

Berdasarkan latar belakang masalah di atas, penulis melakukan penelitian tentang permasalahan kompetensi pedagogik guru dalam sebuah tesis yang berjudul "Hubungan Persepsi Guru tentang Supervisi Kepala Sekolah dan Motivasi Kerja Guru dengan Kompetensi Pedagogik Guru di MAN Kota Bekasi”.

Dari uraian latar belakang masalah di atas, dapat diidentifikasikan beberapa persoalan yang muncul, di antaranya:

1. Apakah terdapat hubungan positifantara persepsi guru tentang supervisi kepala sekolah dan kompetensi pedagogik guru MAN Kota Bekasi secara parsial?

2. Apakah terdapat hubungan positif antara motivasi kerja guru dan kompetensi pedagogik guru di MAN Kota Bekasi secara parsial?

3. Apakah terdapat hubungan positif antara persepsi guru tentang supervisi kepala sekolah dan motivasi kerja guru secara bersama- sama dengan kompetensi pedagogik guru MAN Kota Bekasi?

Agar penelitian ini lebih terfokuskan dan tidak melebar dari persoalan pokok yaitu mengenai kompetensi pedagogik, maka penelitian ini diba- tasi pada pesoalan yang berkaitan dengan:

1. Kompetensi pedagogik guru di Madrasah Aliyah Negeri Kota Bekasi.

2. Persepsi guru tentang supervisi kepala sekolah di Madrasah Aliyah Negeri Kota Bekasi. 
3. Motivasi kerja guru di Madrasah Aliyah Negeri Kota Bekasi.

Berdasarkan pembatasan masalah di atas, maka perumusan masalah yang diajukan dalam penelitian ini adalah sebagai berikut:

1. Bagaimanakah hubunganantara persepsi guru tentang supervisi kepala sekolah dan kompetensi pedagogik guru MAN Kota Bekasi?

2. Bagaimanakah hubungan antara motivasi kerja guru dan kompetensi pedagogik guru di MAN Kota Bekasi?

3. Bagaimanakah hubunganantara persepsi guru tentang supervisi kepala sekolah dan motivasi kerja guru secara bersama-sama dengan kompetensipedagogik guru MAN Kota Bekasi?

Hasil penelitian ini secara teoritis, praktis dan akademis diharapkandapat memotivasi para guru dan akademisi dalam menyalurkan ilmu penge- tahuannya untuk terus melakukan research and development (penelitian dan pengembangan) untuk meningkatkan kualitas pendidikan secara umum.

\section{Kajian Pustaka}

\subsection{Kompetensi Guru dan Hipotesis Riset}

Kata kompetensi berarti "kewenangan (kekuasaan) untuk menentukan (memutuskan sesuatu)".7 Padanan katanya dalam bahasa Inggris, competence, berarti "the ability to do something well: the quality or state of being competent" (kemampuan untuk melakukan suatu pekerjaan dengan baik: kualitas atau keadaan berkompeten). 8 Menurut Cambridge Dictionary kata competence berarti "the ability to do something well"(kemampuan untuk melakukan suatu hal dengan baik).

Kompetensi adalah seperangkat kemampuan yang harus dimiliki oleh seseorang agar ia dapat melaksanakan tugas dengan berhasil. Pemilikan kompetensi dipersyaratkan pada semua bidang profesi. Dalam konteks profesi guru, kompetensi yang harus dimiliki terdiri atas kompetensi pribadi, kompetensi sosial, dan kompetensi profesional mengajar.

Faktor lain yang perlu diperhatikan adalah kinerja. Kinerja guru merupakan hal yang tidak terpisahkan dari kompetensi guru. Seorang guru akan menunjukkan kinerja yang baik apabila ia memiliki sejumlah kompetensi sebagai guru profesional.

Ada lima ukuran seorang guru dinyatakan profesional, yaitu: (a) memiliki komitmen pada siswa dan proses belajarnya; (b) secara mendalam menguasai bahan ajar dan cara mengajarkan; (c) bertanggung jawab dalam memantau kemampuan belajar siswa melalui berbagai teknik evaluasi; (d) mampu berpikir sistematis dalam melakukan tugas; dan (e) seyogyanya menjadi bagian dari masyarakat belajar di lingkungan profesinya.

Dalam Undang-undang No. 14 tahun 2005 Guru dan Dosen Pasal 2 dikatakan bahwa pekerjaan guru dapat dilakukan oleh seseorang yang mempunyai kualifikasi akademik, kompetensi, dan sertifikasi pendidik sesuai dengan persyaratan untuk setiap jenis dan jenjang pendidikan tertentu.

Guru adalah profesi yang sangat strategis dan mulia. Sebagai pewaris nabi, guru harus memaknai tugasnya sebagai amanah Allah SWT untuk mengabdi kepada sesamanya dan berusaha melengkapi dirinya dengan empat sifat utama para nabi yaitu sidiq (benar), amanah (dapat dipercaya), tabliq (mengajarkan semuanya sampai tuntas), dan fathanah (cerdas).

Guru merupakan pekerjaan yang memerlukan keahlian khusus. Jenis pekerjaan ini tidak dapat dilakukan oleh sembarang orang walaupun kenyataannya masih dilakukan oleh orang di luar bidang kependidikan.

Tugas guru sebagai profesi meliputi mendidik, mengajar, dan melatih. Mendidik berarti meneruskan dan mengembangkan nilai-nilai hidup, mengajar berarti meneruskan dan 
mengembangkan ilmu pengetahuan dan teknologi, sedangkan melatih berarti mengembangkan sejumlah keterampilan pada siswa. Seorang guru dituntut mampu menyelaraskan aspek kognitif, afektif, dan psikomotorik dalam proses pembelajaran. Dalam hubungan ini, guru harus memenuhi sejumlah kompetensi tertentu.

Peranan dan kompetensi guru dalam proses belajar-mengajar meliputi banyak hal. Di antara peran dan fungsi tersebut, yang dianggap paling dominan dapat diklasifikasikan dalam empat jenis peran, yaitu: (a) peran guru sebagai demonstrator; (b) peran guru sebagai pengelola kelas; (c) peran guru sebagai mediator dan fasilitator; dan (d) peran guru sebagai evaluator DalamUndang-undang No. 14 Tahun 2005 tentang Guru dan Dosen,Pasal 1 ayat (1) dijelaskan bahwa kompetensi guru adalah seperangkat pengetahuan, keterampilan, dan perilaku yang harus dimiliki, dihayati, dikuasai, dan diaktualisasikan oleh guru dalam melaksanakan tugas profesionalnya. Selanjutnya, dalam Pasal 10 ayat (1) dijelaskan bahwa kompetensi yang dimaksud meliputi: (a) kompetensi pedagogik; (b) kompetensi kepribadian; (c) kompetensi profesional; dan (d) kompetensi sosial.

\subsection{Pengertian Kompetensi Pedagogik}

Dalam Permendiknas Nomor 16 Tahun 2007 tentang Standar Kualifikasi Akademik dan Kompetensi Guru disebutkan bahwa kompetensi peda- gogik adalah kemampuan guru berkenaan dengan penguasaan teoretis dan aplikasinya dalam pembelajaran. Kompetensi pedagogik guru mencakup kompetensi sebagai berikut:

1. Kompetensi menguasai karakteristik perkembangandan kemampuan fisik dan nonfisik peserta didik;

2. Kompetensi menguasai teori belajar dan prinsip-prinsip pembela- jaran;

3. Kompetensi dalam pengembangan kurikulum;

4. Kompetensi dalam penyelenggaraan pembelajaran yang berkualitas;

5. Kompetensi dalam memfasilitasi pengembangan potensi peserta didik;

6. Kompetensi dalam berkomunikasi secara efektif, empatik, dan santun dengan peserta didik;

7. Kompetensi dalam memanfaatkan teknologi pembelajaran;

8. Kompetensi dalam penyelenggaraan dan pemanfaatan penilaian hasil belajar;

9. Kompetensi dalam melakukan tindakan efektif untuk meningkatkan kualitas pembelajaran.

Keharusan guru memiliki kemampuan pedagogik banyak disinggung di dalam Alquran maupun hadis Rasulullah SAW. Salah satu firman Allah yang secara implicit memerintahkan setiap guru membekali diri dengan kemampuan pedagogik adalah surat An-Nahl (16) ayat 125:

"Serulah (manusia) kepada jalan Tuhanmu dengan hikmah dan pelajaran yang baik dan bantahlah mereka dengan cara yang baik. Sesungguhnya Tuhanmu Dialah yang lebih mengetahui tentang siapa yang tersesat dari jalan-Nya dan Dialah yang lebih mengetahui orang-orang yang mendapatkan petunjuk."

Kinerja seorang guru dikatakan baik jika guru telah melakukan unsur- unsur yang terdiri dari kesetiaan dan komitmen yang tinggi pada tugas mengajar, menguasai dan mengembangkan bahan pelajaran, disiplin dalam mengajar dantugas lainnya, kreatif dalam pelaksanaan pengajaran, mampu bekerja sama dengan semua warga sekolah, memiliki kepemimpinan yang menjadi panutan siswa, serta bertanggung jawab terhadap tugasnya. 


\section{Pembahasan}

\subsection{Persepsi Guru tentang Supervisi Kepala Sekolah (X1)}

Persepsi adalah proses mengetahui dan mengenal objek dan kejadian dengan bantuan indera".18 Dalam psikologi kontemporer, persepsi secara umum diperlakukan sebagai suatu variabel campur tangan (interverning variable), bergantung pada faktor-faktor perangsang, cara belajar, perang- kat, keadaan jiwa atau suasana hati, dan faktor-faktor motivasional. Dengan demikian, arti suatu objek atau suatu kejadian objektif ditentu- kan baik oleh kondisi perangsang maupun oleh faktor-faktor organisme. Konsekuensinya, persepsi mengenai dunia oleh pribadi-pribadi yang berbeda juga akan berbeda oleh karena setiap individu menanggapinya berkenaan dengan aspek-aspek situasi yang mengandung arti khusus bagi dirinya.

Psikologi kognitif mengacukepada dunia fisik (eksternal) dan dunia mental (internal) sekaligus. Penghubung realitas eksternal dengan dunia mentalberpusat pada sistem sensorik. Sensasi (sensation) mengacu kepada pendeteksian dini terhadap energi dari dunia fisik, sementara itu persepsi (perception) melibatkan kognitif tingkat tinggi dalam penginterpretasian informasi sensorik. Sensasi mengacu kepada pendeteksian dini terhadap stimuli, sedangkan persepsi mengacu kepada interpretasi hal-hal yang diindra.

Persepsi pada hakikatnya adalahproses kognitif yang dialami oleh setiap orang di dalam memahami informasi tentang lingkungannya, baik lewat penglihatan, pendengaran, penghayatan, perasaan, dan penciuman.20 Persepsi adalah pengalaman tentang objek, peristiwa, atau hubungan- hubungan yang diperoleh dengan menyimpulkan informasi dan menaf- sirkan pesan.

Berdasarkan uraian tentang pengertian persepsioleh para pakar di atas dapat disimpulkan bahwa persepsi adalah proses bagaimakah seseorang menyeleksi, mengatur, dan menginterpretasikan masukan-masukan infor- masi untuk menciptakan gambaran keseluruhan yang berarti. Persepsi dapat diartikan sebagai suatu proses kategorisasi dan interpretasi yang bersifat selektif. Pada umumnya, persepsi berlaku bagi dirinya sendiri dan tidak berlaku bagi orang lain.Selain itu, persepsi dapat berubah seiring dengan berlangsungnya perkembangan pengalaman, perubahan kebutuh- an, dan sikap pribadinya.

Proses pembentukan persepsi diawali oleh masuknya sumber melalui suara, penglihatan, rasa, aroma, atau sentuhan manusia, diterima oleh indera manusia (sensory receptor) sebagai bentuk sensation. Sejumlah besar sensation yang diperoleh dari prosespertama diseleksi. Fungsi penyaringan ini dijalankan oleh sejumlah faktor, seperti harapan individu, motivasi, dan sikap. Sensation yang diperoleh dari hasil penyaringan tahap kedua itu merupakan input bagi proses tahap ketiga, yaitu tahap pengorganisasian sensations. Dari tahap ini akan diperolehsensation yang merupakan satu kesatuan yang lebih teratur dibandingkan dengan sensation sebelumnya. Tahap keempat merupakan tahap penginterpretasian pengalaman, proses belajar, dan kepribadian. Apabila proses ini selesai dilalui akan diperoleh hasil akhir berupa persepsi.

Persepsi merupakan suatu proses yang didahului oleh proses pengin- deraan, yaitu merupakan proses diterimanya stimulus oleh individu melalui alat indra yang disebut proses sensoris. Proses stimulus kemudian berlanjut denganproses persepsi. Dengan demikian, proses persepsi tidak dapat dilepaskan dari proses penginderaan, sedangkan penginderaan merupakan proses pendahulu dari proses persepsi.

Proses penginderaan berlangsung setiap saat oleh alat-alat indra, yaitu melalui mata sebagai alat penglihatan, telinga sebagai alat pendengaran, hidung sebagai alat pembauan, lidah sebagai alat pengecapan, dan kulit telapak tangan sebagai alat perabaan. Semua itu adalah alat indra yang digunakan untuk menerima stimulus dari luar individu. Stimuluis yang 
diindra itu kemudian oleh individu diorganisasikan dan diinterpretasikan sehingga individu menyadari dan mengerti tentang apa yang diindra; proses ini disebut persepsi.

Persepsi merupakan proses yang integratif dalam diri individu terhadap stimulus yang diterimanya. Dengan demikian, persepsi merupakan pengorganisasian dan penginterpretasian terhadap stimulu yang diindra- nya sehingga merupakan sesuatu yang berarti, dan merupakan respons yang terpadu dalam diri individu.

Dalam persepsi, stimulus dapat datang dari luar, tetapi juga dapat datang dari dalam diri individu. Namun demikian, sebagian terbesar stimulus datang dari luar individu yang bersangkutan. Sekalipun persepsi dapat terbentuk melalui bermacam alat indra setiap individu, sebagian besar persepsi terjadi melalui alat indra penglihatan sehingga banyak penelitian mengenai persepsi adalah persepsi yang berkaitan dengan alat peng- lihatan.

Setidaknya terdapat dua teori persepsi yang dikembangkan oleh para peneliti terkait dengan upaya memahami bagaimanakah sebuah sensasi diproses menjadi persepsi terhadap sebuah pola atau suatu objek. Dua teori itu adalah teori persepsi konstruktif (constructive perception) dan teori persepsi langsung (directperception). Menurut teori konstruktif (constructive perception), manusia mengkonstruksi persepsi dengan secara aktif memilih stimuli dan menggabungkan sensasi dengan memori. Sementara itu, menurut teori persepsi langsung (directperception). persepsi terbentuk dari perolehan informasi secarta langsung dari lingkungan.

\subsection{Faktor yang Berperan dalam Persepsi}

Dalam persepsi, individu mengorganisasikan dan menginterpretasikan stimulus yang diterimanya sehingga stimulus tersebut mempunyai arti bagi dirinya. Sehubungan dengan itu, terdapat tiga faktor yang berperan dalam persepsi, yaitu: faktor objek yang dipersepsi,faktor alat indra, syaraf dan pusat susunan syaraf, serta faktor perhatian.

\section{Faktor Objek yang Dipersepsi}

Objek menimbulkan stimulus yang mengenai alat atau indra atau reseptor. Stimulus dapat datang dari luar individu yang mempersepsi tetapi dapat juga datang dari dalam diri individu. Dalam hal ini, sebagian besar stimulus datang dari luar individu.

2. Faktor Alat Indra, Syaraf dan Pusat Susunan Syaraf

Alat indra atau reseptor merupakan alat untuk menerima stimulus. Di samping itu juga harus ada syaraf sensoris sebagai alat untuk meneruskan stimulus yang diterima oleh reseptor ke pusat susunan syaraf yaitu otak sebagai pusat kendaraan.

3. Faktor Perhatian

Untuk menyadari atau untuk mengadakan persepsi diperlukan adanya perhatian, yaitu merupakan langkah pertama sebagai suatu persiapan dalam rangka mengadakan persepsi. Perhatian merupakan pemusatan atau konsentrasi seluruh aktivitas individu yang ditujukan kepada sesuatu atau sekumpulan objek.

Proses pengukuran terhadap persepsi hampir sama dengan proses pengukuran terhadap sikap. Walaupun materi yang diukur bersifat abstrak, secara ilmiah sikap dan persepsi dapat diukur. Dalam hubungan ini, sikap terhadap objekditerjemahkan dalam sistem angka. Dua metode pengukuran sikap terdiri atas metode pengukuran self report dan metode pengukuran involuntary behavior.

Dalam metode pengukuran self report, jawaban yang diberikan oleh responden dapat menjadi indikator sikap seseorang. Kelemahan metode ini terletakpadakemungkinan tidak diberikannya respons oleh pihak yang diharapkan memberikan jawaban. Pada sisi lain, metode pengukuran involuntary behavior digunakan apabila memang dapat dilakukan oleh responden. 
Berdasarkan uraian tentang pengertian persepsioleh para pakar di atas dapat disimpulkan bahwa persepsi adalah proses bagaimakah seseorang menyeleksi, mengatur, dan menginterpretasikan masukan-masukan informasi untuk menciptakan gambaran keseluruhan yang berarti. Persepsi dapat diartikan sebagai suatu proses kategorisasi dan interpretasi yang bersifat selektif. Pada umumnya, persepsi berlaku bagi dirinya sendiri dan tidak berlaku bagi orang lain.Selain itu, persepsi dapat berubah seiring dengan berlangsungnya perkembangan pengalaman, perubahan kebutuhan, dan sikap pribadinya.

\subsection{Pengertian Persepsi Guru tentang Supervisi Kepala Sekolah}

Mengacu kepada kerangka teoretis mengenai pengertian persepsi dan pengertian supervisi kepala sekolah dapat disimpulkan bahwa persepsi guru tentang supervisi kepala sekolah adalah proses mental seorang guru dalam menyeleksi, mengatur, dan menginterpretasikan masukan-masukan informasi untuk menciptakan gambaran keseluruhan yang berarti berkenaan dengan aktivitas supervisi yang dilakukan oleh kepala sekolah. Persepsi guru tentang supervisi kepala sekolah adalah "pandangan dan pendapat guru mengenai pelaksanaan supervisi oleh kepala sekolah di sekolah".

Adapun indikator supervisi kepala sekolah adalah:

1. Perencanaan supervisi.

2. Pelaksanaan supervisi.

3. Tindak lanjut supervisi.

\subsection{Peran Supervisi Kepala Sekolah}

Dari sudut pandang manajemen mutu pendidikan, kepemimpinan pendi- dikan yang direfleksikan oleh kepala sekolah bersifat sangat menentukan. Kepala sekolah sangat berperan dalam usaha meningkatkan mutu pendidikan di satuan pendidikan yang dipimpinnya. Dalam upaya pening- katan mutu pendidikan diperlukan upaya optimalisasi semua komponen, pelaksana, dan kegiatan pendidikan. Salah satu hal penting yang harus dilakukan adalah optimalisasi peran kepala sekolah.

Kepala sekolah adalah pemimpin pendidikan yang mempunyai peranan sangat besar dalam mengembangkan mutu pendidikan di sekolah. Berkembang atau tidaknya semangat kerja, kerja sama yang harmonis, minat terhadap perkembangan pendidikan, serta suasana kerja yang kondusif banyak ditentukan oleh kepemimpinan kepala sekolah. Dalam perspektif kebijakan pendidikan nasional terdapat tujuh peran utama kepala sekolah, yaitu: (a) sebagai pendidik; (b) sebagai manajer; (c) sebagai administrator; (d) sebagai supervisor; (e) sebagai pemimpin (leader); (f) sebagai inovator; (g) sebagai motivator.

Pada dasarnya, kegiatan utama pendidikan di sekolah dalam rangka mewujudkan tujuannya adalah kegiatan pembelajaran sehingga seluruh aktivitas organisasi sekolah bermuara pada pencapaian efisiensi dan efektivitas pembelajaran. Sehubungan dengan itu, salah satu tugas kepala sekolah adalah sebagai supervisor, yaitu melakukan supervisi terhadap pekerjaan yang dilakukan oleh tenaga kependidikan.

Supervisi dalam dunia pendidikan dapat dibedakan menjadi dua macam, yaitu supervisi umum dan supervisi pengajaran.Supervisi umum adalah supervisi yang dilakukan terhadap berbagai kegiatan atau pekerjaan yang secara tidak langsung berhubungan denganusaha perbaikan pengajaran. Adapun supervisi pengajaran adalah kegiatan-kegiatan kepengawasan yang ditujukan untuk memperbaiki kondisi-kondisi, baik personil maupun material, yang memungkinkan terciptanya situasi belajar- mengajar yang lebih baik demi tercapainya tujuan pendidikan. 
Supervisi akademik adalah serangkaian kegiatan membantu guru mengembangkan kemampuannya mengelola proses pembelajaran untuk mencapai tujuan pembelajaran. Supervisi akademik tidak terlepas dari penilaian kinerja guru dalam mengelola pembelajaran.

Refleksi praktis penilaian kinerja guru dalam suatu supervisi akademik adalah melihat kondisi nyata kinerja guru untuk menjawab sejumlah pertanyaan, seperti: apakah yang terjadi di dalam kelas; apakah yang dilakukan oleh guru dan siswa di dalam kelas; aktivitas mana dari keseluruhan aktivitas di dalam kelas yang bermakna bagi guru dan murid. Berdasarkan jawaban terhadap pertanyaan ini akan diperoleh informasi mengenai kemampuan guru dalam mengelola pembelajaranSetelah melakukan penilaian kinerja, aktivitas dilanjutkan dengan pembuatan program supervisi akademik dan melaksanakannya dengan sebaik- baiknya.

\section{Kesimpulan}

Berdasarkan uraian di atas, diajukan hipotesis penelitian sebagai berikut:

1. Terdapat hubungan positif antara persepsi guru tentang supervisi kepala sekolah dan kompetensi pedagogik guru di madrasah aliyah negeri Kota Bekasi.

2. Terdapat hubungan positif antara motivasi kerja dan kompetensi pedagogik guru di madrasah aliyah negeri Kota Bekasi.

3. Terdapat hubungan positif antara persepsi guru tentang supervisi kepala sekolah dan motivasi kerja guru secara bersama-sama dengan kompetensi pedagogik guru di madrasah aliyah negeri Kota Bekasi.

\section{Daftar Pustaka}

Arikunto, Suharsimi. 2006. Dasar-dasar Evaluasi Pendidikan. Jakarta: Bumi Aksara.

Ary, Donald, Lucy Cheser Jacobs \& Asghar Ravazieh. 1979. Introduction to Research in Education. New York: Holt, Rinehart and Winston.

Asro'i. 2013. Studi tentang Kinerja Mengajar Guru: Analisis Pengaruh Kepemimpinan Kepala Madrasah, Budaya Madrasah, Motivasi Kerja, dan Komitmen Kerja terhadap Kinerja Mengajar Guru Madrasah Aliyah se- Kota Bekasi. (Tesis). Sekolah Pascasarjana, Universitas Pendidikan Indonesia, Bandung.

Departemen Pendidikan dan Kebudayaan. 2007. Peraturan Menteri Pendidikan Nasional Republik Indonesia No. 16 Tahun 2007 Tentang Standar Kualifikasi Akademik dan Kompetensi Guru. Jakarta: Depdikbud.

Direktorat Jenderal Peningkatan Mutu Pendidik dan Tenaga Kependidikan. 2008. Pedoman Penilaian Kinerja Kepala Sekolah.Jakarta: Depdiknas.

Direktorat Jenderal Peningkatan Mutu Pendidik dan Tenaga

Kependidikan. 2008. Metode dan Teknik Supervisi. Jakarta: Depdiknas

Djaali. 2009. Psikologi Pendidikan. Jakarta: Bumi Aksara.

Fathoni, Abdurrahmat. 2006. Manajemen Sumber Daya Manusia. Jakarta: Rineka Cipta.

Fattah, Nanang. 1996. Landasan Manajemen Pendidikan. Bandung: Remaja Rosdakarya.

Fraenkel, Jack, Norman Wallen \& Helen Hyun. 2011. How to Design and Evaluate Research in Education. McGraw-Hill.

Glickman, Carl D, Stephen P. Gordon \& Jovita M. Ross-Gordon. 2009. Supervision and Instructional Leadership: A Developmental Approach. Pearson.

Hasibuan, Malayu S.P. 2001. Manajemen: Dasar, Pengertian dan Masalah.

Jakarta: Bumi Aksara.

Kunandar. 2007. Guru Profesional Implementasi Kurikulum Tingkat Satuan Pendidikan.. Jakarta: Raja Grafinso Persada. 
Mulyasa, E. 2003. Menjadi Kepala Sekolah Profesional. Bandung: Remaja Rosda Karya.

Mulyasa, E. 2012. Manajemen dan Kepemimpinan Kepala Sekolah. Jakarta: Bumi Aksara.

Nasution, S. 1995. Didaktik Asas-asas Mengajar. Jakarta: Bumi Aksara. Nasution, S. 2003. Berbagai Pendekatan dalam Proses Belajar Mengajar.

Jakarta: Bumi Aksara

Peraturan Menteri Pendidikan Nasional No. 13 Tahun 2007 tentang Standar Kepala Sekolah.. Peraturan Pemerintah No. 19 Tahun 2005 tentang Standar Nasional Pendidikan.

Peraturan Pemerintah No. 19 Tahun 2007 tentang Standar Pengelolaan Pendidikan oleh Satuan Pendidikan Dasar dan Menengah

Purwanto, Ngalim. 2007. Administrasi dan Supervisi Pendidikan. Bandung: Remaja Rosdakarya.

Roestiyah N.K. 1989. Didaktik Metodik. Jakarta: Bumi Aksara.

Sahertian, Piet. 1990. Supervisi Pendidikan dalam Rangka Program Inservice Education. Jakarta: Rineka Cipta.

Sardiman, A.M. 2012. Interaksi dan Motivasi Belajar Mengajar. Jakarta: Rajawali Press.

Sudjana, Nana. 2004. Penilaian Hasil Proses Belajar Mengajar. Bandung: Remaja Rosdakarya

Suprihatiningrum, Jamil. 2013. Guru Profesional Pedoman Kinerja Kualifikasi dan Kompetensi Guru. Yogyakarta: Ar Ruzz Media.

Suryabrata, Sumadi. 2002. Psikologi Pendidikan. Jakarta: Raja Grafindo Persada.

Sugiyono. 2010. Metode Penelitian Pendidikan. Bandung: Alfabeta. Sugiyono. 2012. Metode Penelitian Kuantitatif Kualitatif R\&D. Bandung:

Alfabeta.

Sukmadinata, Nana Syaodih. 2008. Metode Penelitian Pendidikan. Bandung: Remaja Rosdakarya.

Sukmadinata, Nana Syaodih. 2009. Landasan Psikologi Proses Pendidikan.

Bandung: Remaja Rosdakarya.

Syah, Muhibbin. 2010. Psikologi Pendidikan dengan Pendekatan Baru.

Bandung: Remaja Rosdakarya.

Undang Undang Republik Indonesia No. 20 Tahun 2003 tentang Sistem Pendidikan Nasional.

Undang Undang Republik Indonesia No. 14 Tahun 2005 tentang.Guru dan Dosen.

Uno, Hamzah B. 2010. Teori Motivasi dan Pengukurannya Analisis di Bidang Pendidikan. Jakarta: Bumi Aksara. 